\title{
Analysis and Farmers Perception of Climate Change Trends in Kashmir Region of Union Territory-Jammu \& Kashmir, India: North Western Himalayas
}

\section{S. Sheraz Mahdi ( $\sim$ syedapbau@gmail.com)}

Sher-E-Kashmir University of Agricultural Sciences and Technology Kashmir https://orcid.org/00000001-7418-922X

\section{Bhagyashree Shankarao Dhekale}

Sher-e-Kashmir University of Agricultural Sciences \& Technology of Kashmir

\section{Ashaq Hussain}

Sher-e-Kashmir University of Agricultural Sciences \& Technology of Kashmir

\section{Intikhab Aalum Jehangir}

Sher-e-Kashmir University of Agricultural Sciences \& Technology of Kashmir

\section{Rukhsana Jan}

Sher-e-Kashmir University of Agricultural Sciences \& Technology of Kashmir

\section{Anwar Bhat}

Sher-e-Kashmir University of Agricultural Sciences \& Technology of Kashmir Najeebul Rehman Sofi

Sher-e-Kashmir University of Agricultural Sciences \& Technology of Kashmir

\section{Latief Ahmed}

Sher-e-Kashmir University of Agricultural Sciences \& Technology of Kashmir Asif M. Iqbal Qureshi

Sher-e-Kashmir University of Agricultural Sciences \& Technology of Kashmir Aziz Mujtaba Aezum

Sher-e-Kashmir University of Agricultural Sciences \& Technology of Kashmir Shabir A. Bangroo

Sher-e-Kashmir University of Agricultural Sciences \& Technology of Kashmir

\section{Owais Ali Wani}

Sher-e-Kashmir University of Agricultural Sciences \& Technology of Kashmir

\section{F.A. Bahar}

Sher-e-Kashmir University of Agricultural Sciences \& Technology of Kashmir 
Keywords: Climate change, Weather variables, Annual and seasonal trends, Different elevation zones, Farmers perception

Posted Date: March 12th, 2021

DOI: https://doi.org/10.21203/rs.3.rs-283366/v1

License: (c) (i) This work is licensed under a Creative Commons Attribution 4.0 International License. Read Full License 
Analysis and farmers perception of climate change trends in Kashmir region of Union Territory-Jammu \& Kashmir, India: North Western Himalayas

S. Sheraz Mahdi ${ }^{1}$, B.S. Dhekale ${ }^{2}$, Ashaq Hussain ${ }^{3}$, Intikhab Aalum Jehangir ${ }^{3}$, Rukhsana Jan ${ }^{1}$, M. Anwar Bhat $^{1}$, Najeebul Rehman Sofi ${ }^{3}$, Latief Ahmed ${ }^{4}$, Asif M. Iqbal Qureshi ${ }^{5}$, Aziz Mujtaba Aezum ${ }^{3}$, Shabir A. Bangroo ${ }^{6}$, Owais Ali Wani ${ }^{6}$ and F.A. Bahar ${ }^{1}$

${ }^{1}$ Division of Agronomy, ${ }^{2}$ Division of Agricultural Statistics, ${ }^{3}$ Mountain Research Centre for Field Crops, ${ }^{4}$ Dry Land Agricultural Research Station, ${ }^{5}$ Division of Plant Breeding \& Genetics, ${ }^{6}$ Division of Soil Sciences, Sher-e-Kashmir University of Agricultural Sciences \& Technology of Kashmir, Shalimar-190 025, Srinagar, Union Territory Jammu and Kashmir, India

Corresponding author name: S. Sheraz Mahdi

E-mail: syedapbau@gmail.com 


\begin{abstract}
Analysis of climatic variables is important for detection and attribution of climate change trends and has received a considerable attention from researchers across the globe including India. Kashmir valley of newly formed Union Territory Jammu \& Kashmir situated in north western part of India is having a rich repository of glaciers, a small change in the precipitation and temperature management could introduce about environmental, agricultural and economic penalties. To this end, current study aims to analyse changing patterns in precipitation and temperature variables over the various elevation zones of the Kashmir Valley using long term precipitation and temperature data obtained from National Data Centre, Indian Meteorological Department (IMD), Pune for the period of 40 years (1980-2019). The results revealed that average mean minimum and maximum temperature of the Kashmir valley has increased substantially at a rate of $0.02^{\circ} \mathrm{C} / \mathrm{year}$. Warming trends has been observed in all seasons, however, winter and spring season temperatures have shown statistically significant increasing trends. In addition, mean maximum and minimum temperature in plain and mountain areas have reported higher rates of increase in comparison to Karewah's and foothill areas of Kashmir. Study of annual precipitation results for the same period indicates a diminishing pattern with a rate of $-5.01 \mathrm{~mm} /$ year. Seasonal precipitation was also found decreasing at rate of $-4.95,-0.30,-0.28$ and $-0.06 \mathrm{~mm} /$ year for the spring, winter, autumn and summer seasons respectively and at different elevation zones, higher rates of precipitation decline have been observed in the mountainous area, which can be very detrimental to the agricultural crops of the Kashmir valley through water supply, climate regulation and ground water recharge. Further, the above statistical test results of increase in temperature and decrease in precipitation over different topographical zones of Kashmir were corroborated with the information attained from interview and involvement of the small farmer holders of 06 different locations representing the whole Kashmir and has been discussed in this paper to get a clearer understanding of climate change related instability and patterns in weather variables in the Kashmir Valley.
\end{abstract}

Keywords Climate change. Weather variables . Annual and seasonal trends . Different elevation zones . Farmers perception 


\section{Introduction}

Average surface temperature data of world indicates a linear warming pattern of $0.87^{\circ} \mathrm{C}$ for the recent decade of 2006-2015 and is expected to reach $1.5^{\circ} \mathrm{C}$ between $2030-2052$ (IPCC, 2018). A recently released report by NOAA, (2020), the year 2019 was yet again warmest year with an annual global temperature of $1.1^{\circ} \mathrm{C}$ warmer than the average of 1850-1900. However, air temperatures do not increase equally in all parts of the globe. (Rosenberg et al. 2003). It is also recognized that rainfall is expected to rise by 0.2-0.3 per cent every decade over tropical land in the twenty first century. (IPCC, 2007). Climate change poses a huge danger to agriculture, food security and the livelihoods of millions of people in many parts of the world. (IPCC 2014), wherein, precipitation and temperature are the two main critical variables often used to monitor the degree and severity of climate change and inconsistency. (IPCC 2014).

Union Territory-Jammu and Kashmir of India, situated in the western Himalayan region, are extremely vulnerable to climate change owing to their rugged and high mountain topography. At the same time, the Himalayas, which happens to be the third largest storehouse of frozen water and feeds 1.5 billion people for water on earth are therefore censorious for the water security in the country (DST, 2018). For last few decades, UTJammu \& Kashmir is experiencing the major effect of climate change on local weather in the form of diminishing and reducing glaciers, catastrophic flooding, decreasing winter time and snow, and increasing summer length and temperature. (Solomon et al. 2007; Immerzeel et al. 2010; Romshoo et al. 2015 \& 2017). Therefore, understanding local climate trends and variability has become imperative to settle the impacts of changing climate on agriculture, water resource planning and management to suggest feasible adaptation strategies and agricultural practices for augmenting the valuable inputs for policymakers and practitioners.

In most cases, research on climate change have been done at world level (Pielke et al. 2000), But the window has to be narrowed down to the local level to understand its elaborateness at a micro-level. In addition, complexities become more important for mountain areas, given the geomorphological characteristics, due to their extraordinary impact on local climatic conditions and their interlinking with global climate change. While some records suggest that in western Himalaya, seasonal maximum and minimum temperatures have shown increasing trends by 2.8 and $1^{\circ} \mathrm{C}$ respectively, except Karakoram mountain range where temperatures have shown decreasing trend of $1.6^{\circ} \mathrm{C}$ over the period of two decades (1988-2008) (Shekhar et al. 2010). However, some investigations, including recent one indicates that annual temperatures have risen significantly over the past century (Sharma et al. 2000; Bhutiyani et al. 2010; Shafiq et al. 2016) and has been projected around 0.16 degree Celsius per ten years over Himalayas during last hundred years (Bhutiyani et al. 2007). Other studies in Indian Himalayas especially in the west parts have observed increasing trends of temperature by $0.9^{\circ} \mathrm{C} / \mathrm{dec} a d e(1901-2003)$ (Dash et al. 2007), the study further revealed that the majority of this higher temperature trend have been increased after 1972 in particular. In addition, Dimri and Dash (2012) while studying the temperature trends of the winter months from 1975 to 2006, has reported increasing trend over western Himalayas with mean maximum temperature recorded largest rise $\left(1.1-2.5^{\circ} \mathrm{C}\right)$.

From the ongoing deliberation, the pattern studies performed so far in the Himalayan region are not definitive and some are conducted on a macro scale, which requires more investigation. This has shown that relying on the annual or seasonal pattern alone cannot be deceive and should be accompanied by a variability study. Further, the perception and experience of farmers pertaining to weather and climate change has not been included in any of the study. Incorporating farmers' views of shifts in weather and environment in the pattern study 
may provide an important insight into the essence of weather cycles that could not be captured by the review of long-term weather records alone.

As a result, this research combines both the variability inquiry, the pattern review (based on historical evidence from 1980 to 2019) using descriptive and predictive measures, and the understanding of smallholders and marginal farmers from various topographical locations, so as to give a better understanding of climate change induced variability and pattern of meteorological variables in the Kashmir Valley.

\section{Study location}

The Union territory-Jammu and Kashmir (Figure 1) located in the extreme north-western Himalaya of India, between longitude $72^{\circ} 31^{\prime} \mathrm{E}$ and $80^{\circ} 20^{\prime} \mathrm{E}$ and Latitude $32^{\circ} 17^{\prime} \mathrm{N}$ and $37^{\circ} 05^{\prime} \mathrm{N}$. This region is bestowed with subtropical and temperate climate. The Kashmir valley $\left(33^{\circ} 22^{\prime}\right.$ to $34^{\circ} 50^{\prime} \mathrm{N}$ latitude and $73^{\circ} 52^{\prime}$ to $75^{\circ} 42^{\prime} \mathrm{E}$ longitudes) lying in the temperate zone is extended over an area of 15, 948 sq. km, surrounded by the Pir Panjal from northern and western ends of the greater Himalayas in the south-east, which stops monsoon winds from the southeast and south, and cold winds from Central Asia in the Kashmir Valley. As such, the climate of sheltered Valley has its own peculiarities and exhibits exception to peripheral region. The valley area is normally bordered on all sides by mountains with an average valley height of $1620 \mathrm{~m}$, but the surrounding snow-clad mountains climb from 3000 to $4900 \mathrm{~m}$. The climate of Kashmir differs greatly due to its harsh topography, it plays an important role in people's lives, availability of basic necessities and in the socio-economic growth of the region of the Union as a whole.

\section{Data and methodology}

\subsection{Data}

A long-term data sets of six meteorological stations spanning over Kashmir valley (Fig. 1) on maximum, minimum temperatures and precipitation obtained from National Data Centre, Indian Meteorological Department, Pune and Srinagar for the period 1980-2019 were analysed in this study. Data were used to measure annual and seasonal temperature and precipitation variations across the chosen regions of study. For intra-annual variations, the monthly data was split into four seasons: summer as June, July, August; spring as March, April, May; autumn as September, October, November and winter as December, January, February. Although the overall consistency of the data collection used was reasonably high, some of the stations examined in the analysis had holes of less than $5 \%$ of the total observations. With regard to the probability of filling these holes, easy imputation was used to fill the missed gaps in the relevant decade by measuring the decadal daily averages (Johnson, 2003).

\subsection{Methodology}

\subsubsection{Descriptive analysis}

Descriptive statistic like mean, standard deviation, and variance were computed. Other statistical computations were also included as kurtosis, skewness and coefficient of variations.

\subsubsection{Correlation Analysis}

Correlation analysis among the weather variables and with time for all six meteorological stations was computed by standard procedure in $\mathrm{R}$ environment.

\subsubsection{Trend detection}

The patterns in long period of meteorological data can be identified using a large range of experiments (Tabari et al. 2011). In this analysis, both linear regression viz. parametric and Man-Kendall viz. non parametric methods were employed to identify patterns in temperature and rainfall. Being simple in calculations, the 
parametric methods are often preferred (Mosmann et al. 2004). However, the restriction of normal distribution in case of these parametric test can be overcome by allowing transformations of data set (Huth, 1999). However, non-parametric methods are distribution free and power of these tests are equally comparable to the parametric one (Zhang et al. 2008). The short explanations of the statistical techniques used are as follows:

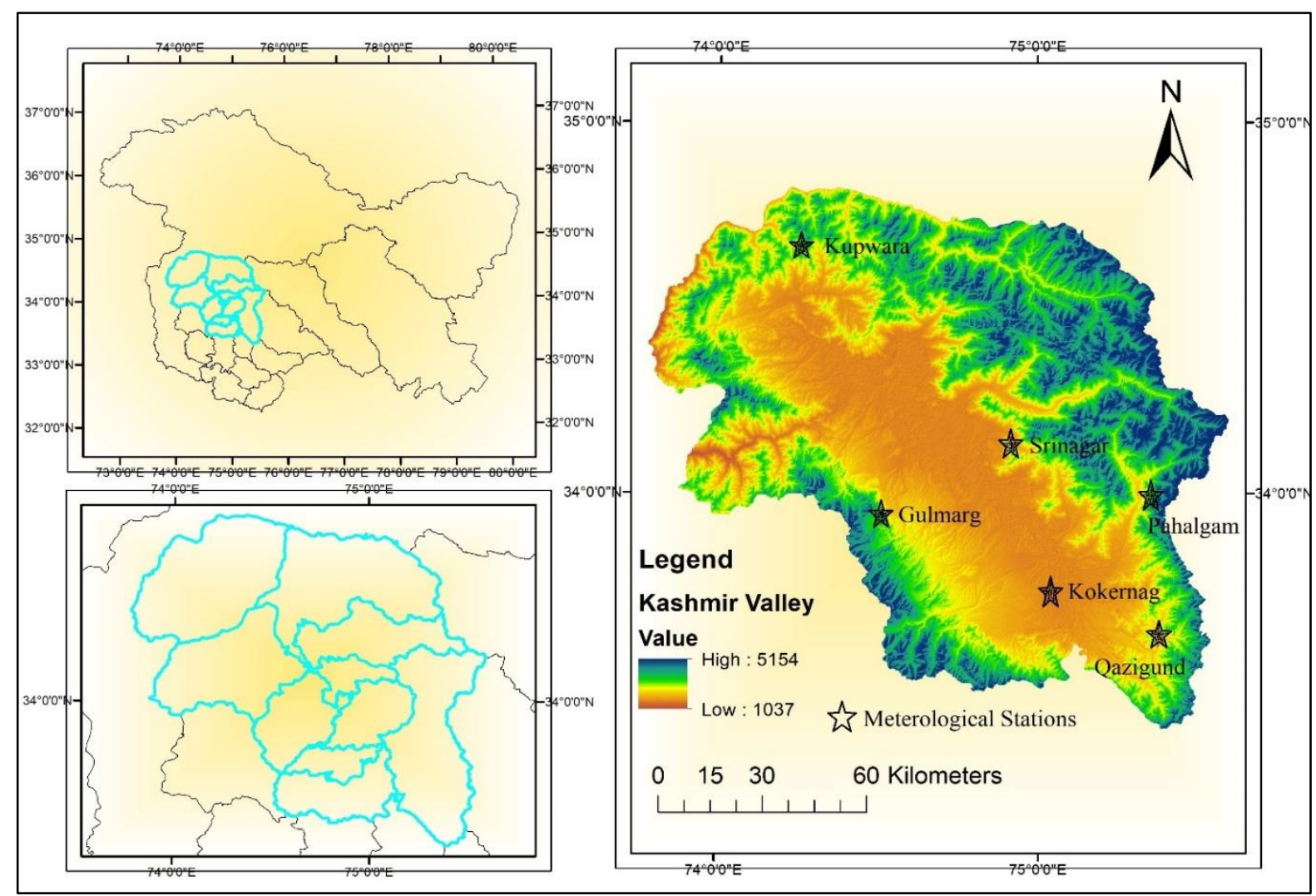

Figure 1. Map showing the locations and elevation $(\mathrm{m})$ of six meteorological stations used in the study viz., Srinagar (flood plain, located on plane surface), Quazigund (foot hills, located on plane surface), Gulmarg and Pahalgham (Mountainous, located on mountain top), Kupwara (Karewa's, located on plane surface bounded on three sides by mountains) and Kokernag (Karewa's, located on plane surface) of UT-Jammu \& Kashmir. Data period used: (1980-2019)

\subsubsection{Trend test given by Mann Kendall (MK)}

The Mann-Kendall identifies the patterns in time series and is non - parametric test. Instead of comparing the data values themselves, this test compares the relative magnitude of the input data (Gilbert, 1987). Being nonparametric test, results of the test does not stick to any distribution of the series. Moreover, due time series is nonhomogenous is low vulnerable to sudden breaks (Jaagus, 2006). Mann (1945) first used this measure and Kendall (1975) eventually derived the statistical distribution of the test. According to this research, the null hypothesis in the test is that there is no proper trend in the data set. Significance of the test rejects the null hypothesis which means that the pattern is present throughout the data set, and can be either positive or negative as defined in the ranking. The test statistic $S$ is given by:

$$
S=\sum_{k=1}^{n-1} \sum_{j=k+1}^{n} \operatorname{sgn}\left(x_{j}-x_{k}\right)
$$

The pattern test is protracted to the time series $\mathrm{xk}$, where $\mathrm{k}$ ranges from $1,2,3, \ldots \mathrm{n}-1$ and $\mathrm{xj}$ is reference point which are ranked from $\mathrm{j}=\mathrm{I}+1, \mathrm{I}+2, \mathrm{I}+3, \ldots \mathrm{n}$. and is compared to the rest of the data points xk, such that, 
$\operatorname{sgn}\left(x_{j}-x_{k}\right)=\left\{\begin{array}{r}+1 \text { if } x_{j}-x_{k}>0 \\ 0 \text { if } x_{j}-x_{k}=0 \\ -1 \text { if } x_{j}-x_{k}>0\end{array}\right.$

Here are the sequential data values of $\mathrm{xj}$ and $\mathrm{xk}$, and $\mathrm{n}$ is the length of the data set. For samples greater than 10, the procedure is performed using a normal distribution (Helsel et al. 1992) with the mean and variance as follows and the variance for the $\mathrm{S}$ statistic is defined as:

$$
E(S)=0
$$

$\operatorname{VAR}(S)=\frac{1}{18}\left[n(n-1)(2 n+5)-\sum_{p=1}^{q} t_{p}\left(t_{p}-1\right)\left(2 t_{p}+5\right)\right]$

Here tp is the number of data points in the pth bound group, and q is the number of bound groups in the data set. The uniform Zmk test statistic is determined by:

$Z m k= \begin{cases}\frac{S-1}{\sqrt{\operatorname{VAR}(S)}} & \text { if } S>0 \\ 0 & \text { if } S=0 \\ \frac{S+1}{\sqrt{\operatorname{VAR}(S)}} & \text { if } S<0\end{cases}$

Where the value of Zmk is the Mann-Kendall test statistics which follow the standard normal distribution with a mean of zero and a variance of one. Thus, in a two-sided trend test, the null HO hypothesis is agreed if $-\mathrm{Z}_{1}$ $-\alpha / 2 \leq Z_{\mathrm{mk}} \leq Z_{1}-\alpha / 2$, where $\alpha$ is the degree of importance that indicates the intensity of the trend.

\subsubsection{Sen's Slope Estimator}

Man Kendall test used to identify weather pattern present in data series, however the magnitude of the pattern can be estimated by Sen estimator which is non-parametric used in time series (Sen, 1968). Sen's nonparametric method is used to measure the true slope of the current trend, such as the rate of change each year. However, linearity in pattern of time series is main restriction of Sen estimator, such as:

$$
f(t)=Q t+B
$$

Here $\mathrm{Q}$ is the slope, and $\mathrm{B}$ is a constant.

To get the slope estimate $Q$ in Eq. 5, the slopes of all the data value pairs are calculated as:

$$
Q_{i}=\frac{x_{j}-x_{k}}{j-k}
$$

Here $x_{j}$, and $x_{k}$ are the data values in years $j$ and $k, j>k$. If there are $n$ values of $x_{j}$ in the time series, one gets as many as $N=n(n-1) / 2$ slope estimates $Q_{i}$.

Sen's estimator of the slope is the median of these $N$ values of $Q_{i}$. The $N$ values of $Q_{i}$ are ranked from the smallest to the largest, and Sen's estimator is

$$
\begin{array}{ll}
Q=Q_{[(N+1) / 2]} & \text { if } \mathrm{N} \text { is odd } \\
\mathrm{Q}=\frac{1}{2}\left(Q_{[N / 2]}+Q_{[(N+1) / 2]}\right) & \text { if } \mathrm{N} \text { is even }
\end{array}
$$

The either sided confidence interval of the slope estimation can be obtained by nonparametric technique considering normal distribution. Sen Slope estimator can be accurately calculated for sample size as small as 10 unless there are a number of relations. A positive Qi value indicates an upward trend, while a negative value indicates a downward trend in the time sequence. 


\subsubsection{Linear regression}

Simple linear regression widely used parametric approach for the detection of linear trend in time series. It is used to identify the relationship between one variable and another variable or other variables of interest. The slope of hydrometeorological factors is also carried out on schedule. Positive slope values indicate a rising trend, while negative slope values show a declining trend. Regression has the advantage that it offers a metric of importance dependent on the slope hypothesis test and also gives the magnitude of the rate of change viz. regression coefficient (Hirsch et al. 1991). The cumulative adjustment over the time under study is achieved by multiplying the slope by the number of years. In this work, the patterns were found to be statistically relevant at $\alpha<0.05$ level using the Student T-Test.

\section{Results and discussion}

\subsection{Temperature}

\subsubsection{Monthly, annual and seasonal analysis of maximum temperature}

Figures 2a shows box plot for the dispersal of the monthly maximum temperature for each meteorological station in Kashmir. The duration of the box clearly shows the temperature variability is more during the month of January, March, May and November, whereas, June, July and August months are more stable months. The mean monthly maximum temperature reaches to its peak during the month of July, after which it starts declining and reaches to its lowest during December and January. Looking at skewness values (Table 1a), it is observed that December month exhibited high negative skewness value indicating the tendency of temperature to remain below average. High positive kurtosis value signifies the heavy tailed distribution i.e., more outliers present in the data set. Both can be easily seen from the box plot diagram where for December month, more below average outliers are seen. The value of skewness and kurtosis were observed positively high for the month of April, which indicates tendency of temperature to remain more than average and can be seen through box plot where large whisker and outlier is observed towards high end during the April month.

The correlation matrix for all meteorological stations between weather variables and with time is presented in Figure 3 (a-f). It is observed that, maximum temperature shows positively significant correlation with time for Srinagar, Pahalgam and Kupwara. However, for stations like Gulmerg, Quazigund and Kokernag, the correlation is positively nonsignificant $(p<0.05)$. This indicates, temperature has been increasing over the years for all stations. With respect to correlation between maximum with minimum temperature and rainfall. The perusal of data indicates that with increase in maximum temperature, the minimum temperature significantly $(p<0.05)$ increasing except Kokernag and rainfall is significantly decreasing at all stations representing the different geolocations of Kashmir.

The study of annual and seasonal temperature patterns during the period of 1980-2019 was also performed. Mann-Kendall test indicates a substantial rise $(p=0.06)$ in mean annual maximum temperature in the entire valley at a pace of $0.02^{\circ} \mathrm{C} /$ year over the span of forty years (Fig. 4a). It also suggests a large phase jump in 1997 ( $p=0.01$ ), which illustrates quantum difference in maximum temperature, with recent decades indicating larger maximum temperature ranges than the original years of the research period. The review of the data shown in Table 2 indicates that, with the exception of summer and fall, the mean temperatures during the winter and spring seasons display a statistically important growing pattern. The growing pattern in winter may prove to be harmful to the valley's glaciofluvial climate and may have a negative effect on agricultural and fruit crops such as apples, barley, oilseeds and winter pulses, which require winter cooling during the spring season. 
In-situ temperature data obtained from the six stations under varying topographical conditions have also been studied. It was observed that the mean maximum temperature showed an increasing trend with variability among the various topographic locations, i.e., flood plains (constitute, Srinagar) showing yearly proportion of increase by $0.03^{\circ} \mathrm{C} /$ year, followed by mountains (constitute, Gulmarg and Pahalgam) by $0.02^{\circ} \mathrm{C} /$ year, foot hills (constitute, Qazigund) at $0.01{ }^{\circ} \mathrm{C} /$ year and Karewa's (comparising Kupwara and Kokernag meteorological observatory) at $0.01{ }^{\circ} \mathrm{C} /$ year (Fig. 5a). The higher rate of increase in temperature in flood plains, comprising mainly Srinagar city may be attributed to 'urban heat island effect' (Pawe, 2019; Nengroo et al. 2017). Whereas, in mountainous ecosystem, elevation-dependent warming (EDW) might have accelerated the rate of change in temperature, where warming rate is loudened with elevation (Pepin et al. 2015). In addition, statistically important phase jumps in various topographical zones were found in 1997 ( $p=0.01)$, which obviously indicates that mean maximum temperatures have risen.

\subsubsection{Monthly, annual and seasonal analysis of minimum temperature}

Mean monthly distribution of minimum temperature indicates homogenous variability for all months across different meteorological stations (Fig. 2b). The minimum temperatures remain comparatively higher during June, July and August and dips down to $-5^{\circ} \mathrm{C}$ or below during the month of January. From Table $1 \mathrm{~b}$, considerable variation in minimum temperature has been observed during winter season and recorded highest during month of November (244\%) and minimum temperature fluctuates alternately in positive and negative direction, which could lead to large variation in minimum temperature. Other parameter like skewness and kurtosis are normal, however, kurtosis value for the month October is quite high, indicating heavy tailed distribution of temperature. During summer season, temperatures remain more or less similar and hence the CV values are less and consistent over season.

The correlation pattern between minimum temperature with time indicates significant positive relationship for stations viz. Srinagar, Quazigund and Kokernarg, whereas, a non-significant positive correlation was observed for rest of the stations like Gulmerg, Kupwara and Pahalgam (Figure 3 a-f). This signifies that minimum temperature is also showing increasing trend over the study area.

Furthermore, the related trends in the annual mean minimum temperature indicate an improvement at a rate of around $0.02{ }^{\circ} \mathrm{C} /$ year, with the Mann-Kendall test demonstrating a statistically rising pattern $(p=0.001)($ Fig. 4b), the year of adjustment was 1996, which indicates a substantial step-up of evidence for recent decades in a higher range than in the early years. Further, the data presented in Table 2 indicates increase in minimum temperature in all seasons with spring season showing statistically significant increasing trend $(p=0.02)$. At different elevation zones, the mean minimum temperatures have shown a visible change in the past two decades and is quite prominent from 1996 onwards showing a substantial phase jump. Average minimum temperature at various elevations shows comparatively lower rates of increase with at rapid pace at flood plains and mountainous regions $\left(0.02{ }^{\circ} \mathrm{C} /\right.$ year $)$ followed by Karewa's with increase of $0.01^{\circ} \mathrm{C} /$ year and lowest rate of increase in minimum temperature has been observed over foothills at $0.004{ }^{\circ} \mathrm{C} /$ year (Fig. 5b). The above results are clear and justifies that climate at regional level has slowly but unquestionably changed over time. (Wang et al. 2008; Brohan et al. 2006; Yao and Chen 2015; IPCC 2007). 
Table 1. Statistical information of a) maximum, b) minimum and c) rainfall of Kashmir Valley of UT-Jammu \& Kashmir

a) Maximum temperature $\left({ }^{\circ} \mathrm{C}\right)$

\begin{tabular}{lccccccc}
\hline Month & Maximum & Minimum & Mean & SD & CV (\%) & Skewness & Kurtosis \\
\hline January & 9.54 & -0.40 & 5.33 & 2.19 & 41.03 & 0.02 & 0.13 \\
February & 11.93 & 3.73 & 7.46 & 1.89 & 25.38 & 0.45 & 0.17 \\
March & 18.51 & 7.94 & 12.28 & 2.53 & 20.56 & 0.71 & -0.01 \\
April & 23.33 & 14.91 & 17.90 & 1.72 & 9.62 & 0.86 & 1.39 \\
May & 27.23 & 17.76 & 22.17 & 2.01 & 9.05 & 0.33 & 0.14 \\
June & 28.74 & 22.71 & 25.75 & 1.34 & 5.19 & -0.32 & -0.07 \\
July & 28.88 & 25.15 & 27.02 & 0.78 & 2.89 & -0.09 & 0.45 \\
August & 28.47 & 25.26 & 26.89 & 0.81 & 3.02 & -0.03 & -0.43 \\
September & 27.64 & 21.89 & 25.12 & 1.24 & 4.95 & -0.30 & 0.42 \\
October & 23.32 & 16.68 & 20.32 & 1.57 & 7.73 & -0.33 & -0.19 \\
November & 17.34 & 8.72 & 13.95 & 1.82 & 13.01 & -0.46 & 0.43 \\
December & 11.64 & 2.13 & 8.13 & 1.84 & 22.69 & -0.98 & 2.23 \\
\hline
\end{tabular}

b) Minimum temperature $\left(\left({ }^{\circ} \mathrm{C}\right)\right.$

\begin{tabular}{lccccccc}
\hline Month & Maximum & Minimum & Mean & SD & CV $(\%)$ & Skewness & Kurtosis \\
\hline January & -1.53 & -7.90 & -4.19 & 1.50 & -35.81 & -0.65 & 0.74 \\
February & 1.26 & -4.91 & -2.20 & 1.29 & -58.79 & 0.05 & 0.56 \\
March & 3.82 & -1.12 & 1.40 & 1.06 & 75.57 & 0.04 & 0.21 \\
April & 6.76 & 3.67 & 5.37 & 0.77 & 14.37 & -0.31 & -0.74 \\
May & 10.97 & 6.85 & 8.58 & 0.99 & 11.49 & 0.46 & 0.15 \\
June & 15.41 & 10.11 & 12.01 & 1.13 & 9.40 & 0.65 & 0.86 \\
July & 17.15 & 12.62 & 15.43 & 0.96 & 6.24 & -0.70 & 0.63 \\
August & 17.10 & 13.26 & 15.00 & 0.80 & 5.33 & 0.19 & 0.46 \\
September & 12.06 & 8.41 & 10.60 & 0.95 & 8.92 & -0.42 & -0.73 \\
October & 8.02 & 3.42 & 4.86 & 0.89 & 18.25 & 1.03 & 2.75 \\
November & 2.12 & -1.07 & 0.32 & 0.77 & 243.91 & 0.29 & 0.05 \\
December & -0.87 & -4.94 & -2.66 & 1.03 & -38.78 & -0.57 & -0.44 \\
\hline \multicolumn{1}{c}{ c) Precipitation (mm) } & & & & & & \\
\hline Month & Maximum & Minimum & Mean & SD & CV $(\%)$ & Skewness & Kurtosis \\
\hline January & 272.90 & 5.45 & 104.24 & 60.68 & 58.21 & 0.44 & 0.26 \\
February & 395.85 & 29.03 & 147.87 & 71.27 & 48.19 & 1.21 & 2.73 \\
March & 411.57 & 15.28 & 183.39 & 97.55 & 53.19 & 0.41 & -0.67 \\
April & 259.87 & 17.27 & 136.55 & 60.23 & 44.11 & 0.08 & -0.15 \\
May & 262.17 & 39.82 & 106.64 & 48.82 & 45.78 & 1.38 & 2.53 \\
June & 179.43 & 25.07 & 77.54 & 37.17 & 47.93 & 1.03 & 0.81 \\
July & 197.13 & 44.27 & 91.54 & 37.18 & 40.62 & 1.15 & 1.07 \\
August & 212.80 & 27.33 & 82.24 & 39.68 & 48.25 & 1.53 & 3.12 \\
September & 342.72 & 9.23 & 61.16 & 56.44 & 92.29 & 3.41 & 15.62 \\
October & 205.18 & 0.20 & 43.38 & 38.68 & 89.16 & 2.22 & 7.01 \\
November & 251.73 & 0.00 & 47.27 & 49.34 & 104.38 & 2.28 & 6.94 \\
December & 302.08 & 0.00 & 63.77 & 61.59 & 96.58 & 1.96 & 4.89 \\
\hline
\end{tabular}



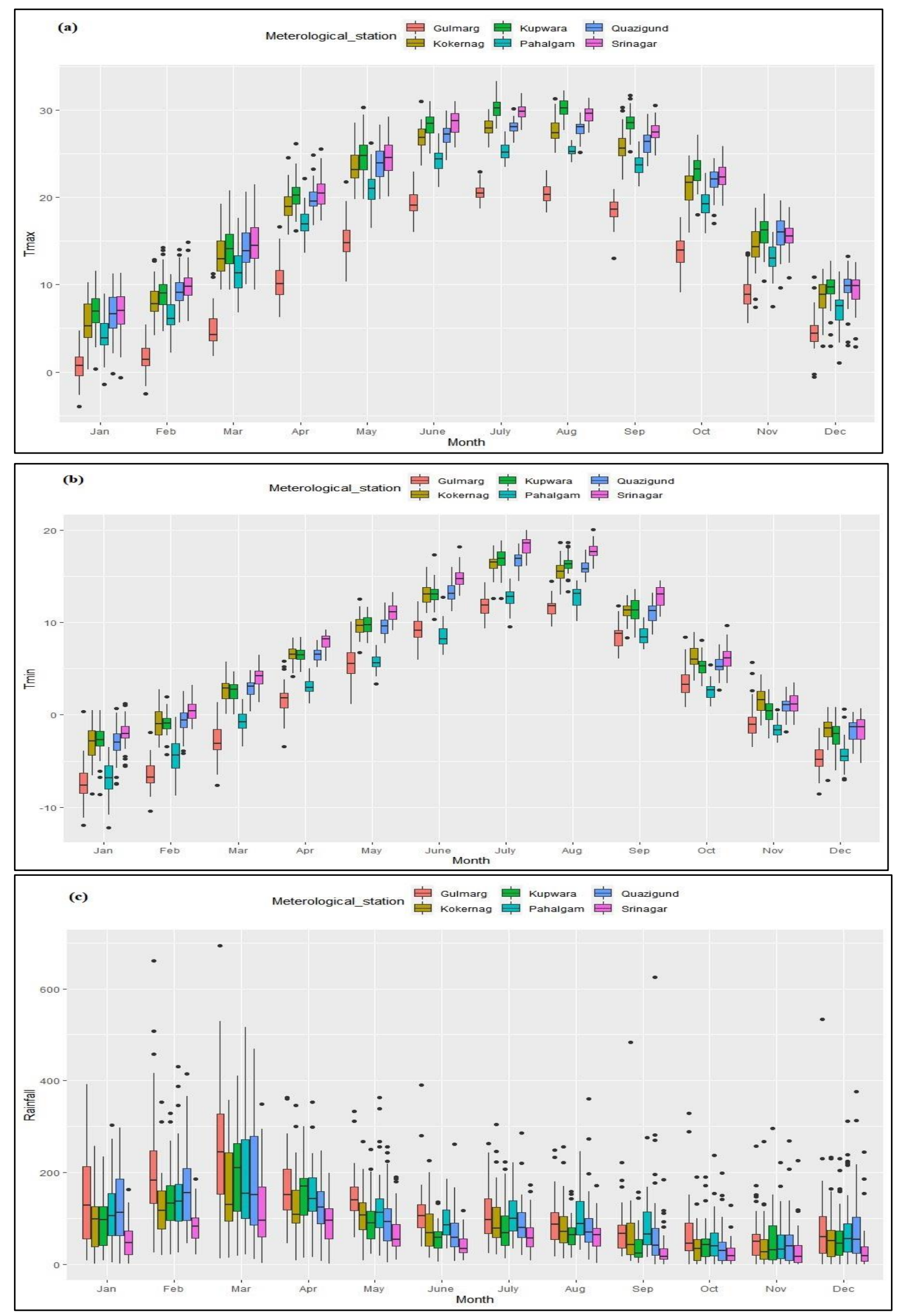

Figure 2. Mean monthly (a) maximum, (b)minimum and (c) rainfall of six meteorological stations from 19802019 representing Kashmir Valley of UT-Jammu \& Kashmir, India 

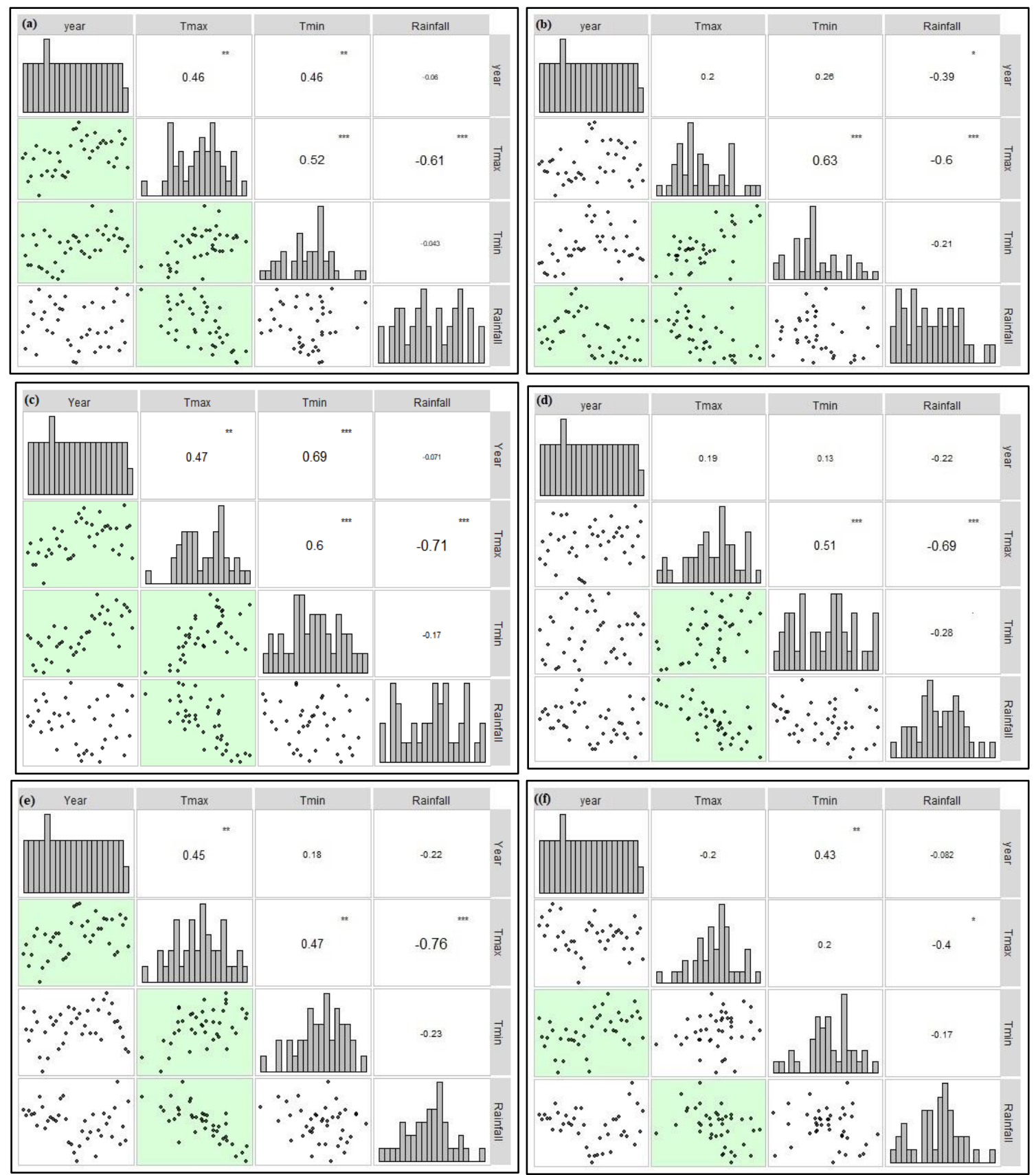

Figure 3 (a-f) Pair plot of correlation matrix among different weather variables across six meteorological stations viz. (a) Srinagar, (b) Gulmarg, (c) Pahalgham, (d) Quazigund, (e) Kupwara and (f) Kokernag of Kashmir valley of UT-Jammu and Kashmir, India. Data period used: (1980-2019) 

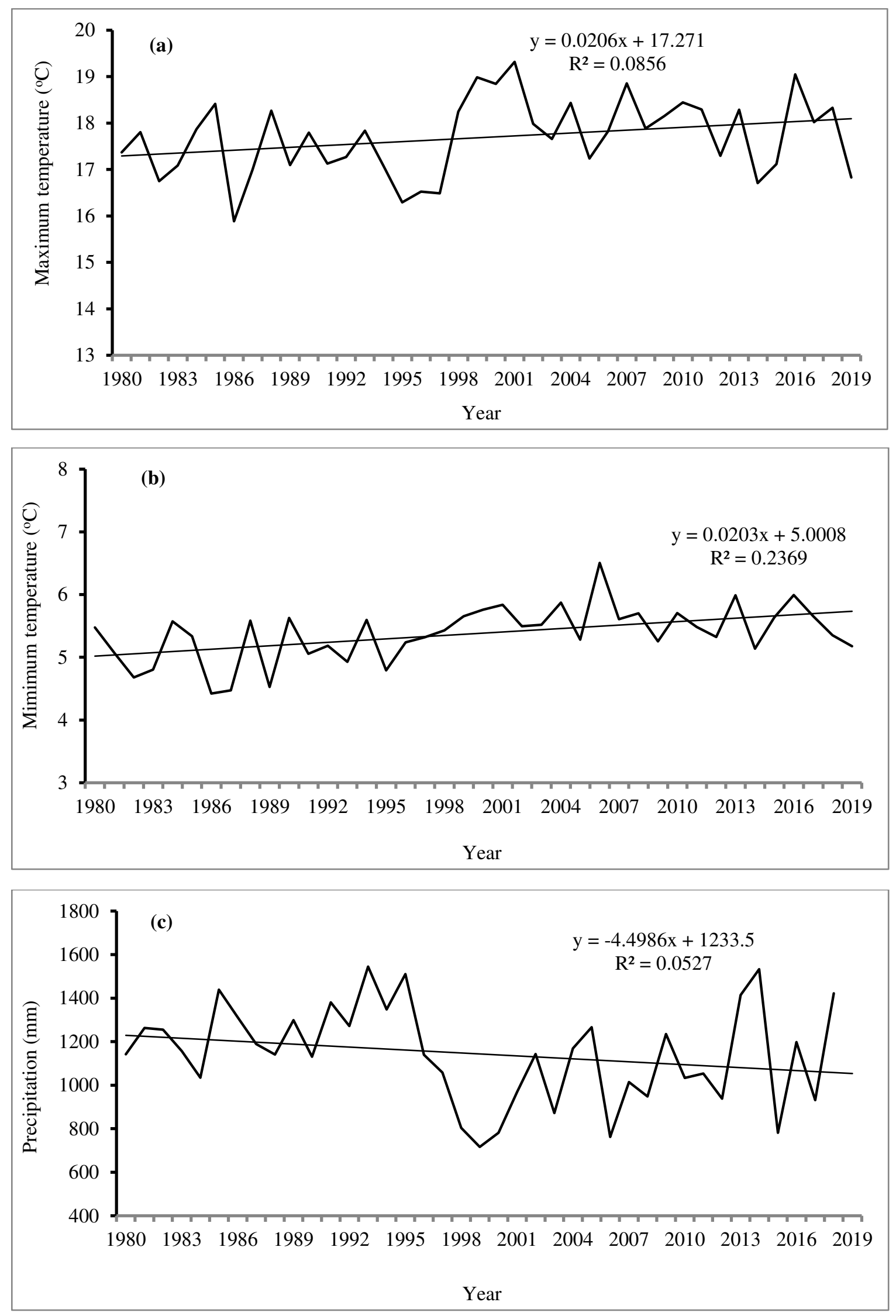

Fig. 4 Trends of mean annual (a) maximum (b) minimum temperature and (c) rainfall of Kashmir Valley of UTJammu \& Kashmir, India 
Table 2 Seasonal and annual Mann-Kendall trend data on temperature and precipitation at various stations of Kashmir Valley from 1980 to 2019. (The values in the parenthesis are the degree of significance)

\begin{tabular}{|c|c|c|c|c|c|c|c|}
\hline $\begin{array}{l}\text { Meteorological } \\
\text { Station }\end{array}$ & \multicolumn{2}{|c|}{$\begin{array}{l}\text { Meteorological } \\
\text { Parameters }\end{array}$} & Winter & Spring & Summer & Autumn & Annual \\
\hline Kashmir Valley & $\begin{array}{l}\mathrm{T}\left({ }^{\mathrm{o}} \mathrm{C}\right) \\
\mathrm{P}(\mathrm{mm})\end{array}$ & $\begin{array}{l}\text { Max } \\
\text { Min }\end{array}$ & $\begin{array}{l}0.05(0.008) \\
0.02 \\
-0.30\end{array}$ & $\begin{array}{l}0.04(0.03) \\
0.021(0.02) \\
-4.95(0.02)\end{array}$ & $\begin{array}{l}-0.012 \\
0.01 \\
-0.06\end{array}$ & $\begin{array}{l}-0.003 \\
0.025(0.001) \\
-0.28\end{array}$ & $\begin{array}{l}0.020(0.06) \\
0.017(0.001) \\
-5.01\end{array}$ \\
\hline Srinagar & $\begin{array}{l}\mathrm{T}\left({ }^{\circ} \mathrm{C}\right) \\
\mathrm{P}(\mathrm{mm})\end{array}$ & $\begin{array}{l}\text { Max } \\
\text { Min }\end{array}$ & $\begin{array}{l}0.07(0.05) \\
0.004 \\
1.03\end{array}$ & $\begin{array}{l}0.05(0.02) \\
0.02(0.01) \\
-2.22\end{array}$ & $\begin{array}{l}-0.002 \\
0.014 \\
-0.08\end{array}$ & $\begin{array}{l}0.02 \\
0.03(0.001) \\
-0.22\end{array}$ & $\begin{array}{l}0.03(0.004) \\
0.01(0.01) \\
-0.55\end{array}$ \\
\hline Quazigund & $\begin{array}{l}\mathrm{T}\left({ }^{\mathrm{o}} \mathrm{C}\right) \\
\mathrm{P}(\mathrm{mm})\end{array}$ & $\begin{array}{l}\text { Max } \\
\text { Min }\end{array}$ & $\begin{array}{l}0.04(0.05) \\
0.01 \\
-1.9\end{array}$ & $\begin{array}{l}0.04(0.03) \\
0.004 \\
-5.3(0.01)\end{array}$ & $\begin{array}{l}-0.005 \\
0.01 \\
0.60\end{array}$ & $\begin{array}{l}-0.03(0.04) \\
-0.001 \\
0.18\end{array}$ & $\begin{array}{l}0.014 \\
0.004 \\
-5.70\end{array}$ \\
\hline Pahalgham & $\begin{array}{l}\mathrm{T}\left({ }^{\mathrm{o}} \mathrm{C}\right) \\
\mathrm{P}(\mathrm{mm})\end{array}$ & $\begin{array}{l}\text { Max } \\
\text { Min }\end{array}$ & $\begin{array}{l}0.08(0.001) \\
0.06(0.001) \\
0.65\end{array}$ & $\begin{array}{l}0.05(0.01) \\
0.03(0.001) \\
-4.67(0.02)\end{array}$ & $\begin{array}{l}-0.01 \\
0.05(0.001) \\
0.58\end{array}$ & $\begin{array}{l}0.03 \\
0.03(0.001) \\
1.54\end{array}$ & $\begin{array}{l}0.04(0.01) \\
0.04(0.001) \\
-1.35\end{array}$ \\
\hline Gulmarg & $\begin{array}{l}\mathrm{T}\left({ }^{\circ} \mathrm{C}\right) \\
\mathrm{P}(\mathrm{mm})\end{array}$ & $\begin{array}{l}\text { Max } \\
\text { Min }\end{array}$ & $\begin{array}{l}0.03 \\
0.04(0.01) \\
-2.82 \\
\end{array}$ & $\begin{array}{l}0.05(0.04) \\
0.03(0.05) \\
-7.3(0.01)\end{array}$ & $\begin{array}{l}-0.01 \\
-0.01 \\
-1.68 \\
\end{array}$ & $\begin{array}{l}0.05 \\
0.03 \\
-0.14 \\
\end{array}$ & $\begin{array}{l}0.01 \\
0.02 \\
-12.1(0.03)\end{array}$ \\
\hline Kupwara & $\begin{array}{l}\mathrm{T}\left({ }^{\circ} \mathrm{C}\right) \\
\mathrm{P}(\mathrm{mm})\end{array}$ & $\begin{array}{l}\text { Max } \\
\text { Min }\end{array}$ & $\begin{array}{l}0.06(0.002) \\
-0.001 \\
0.15\end{array}$ & $\begin{array}{l}0.06(0.02) \\
0.011 \\
-3.99(0.04)\end{array}$ & $\begin{array}{l}0.01 \\
0.007 \\
-1.29\end{array}$ & $\begin{array}{l}0.02 \\
0.015 \\
-0.16\end{array}$ & $\begin{array}{l}0.04(0.05) \\
0.007 \\
-5.52(0.09)\end{array}$ \\
\hline Kokernag & $\begin{array}{l}\mathrm{T}\left({ }^{\circ} \mathrm{C}\right) \\
\mathrm{P}(\mathrm{mm})\end{array}$ & $\begin{array}{l}\text { Max } \\
\text { Min }\end{array}$ & $\begin{array}{l}0.02 \\
0.02 \\
-0.60\end{array}$ & $\begin{array}{l}0.02 \\
0.03(0.01) \\
-4.2(0.04)\end{array}$ & $\begin{array}{l}-0.05(0.001) \\
-0.001 \\
1.15\end{array}$ & $\begin{array}{l}-0.06(0.002) \\
0.06(0.001) \\
-0.32\end{array}$ & $\begin{array}{l}-0.02 \\
0.02(0.01) \\
-3.6\end{array}$ \\
\hline
\end{tabular}

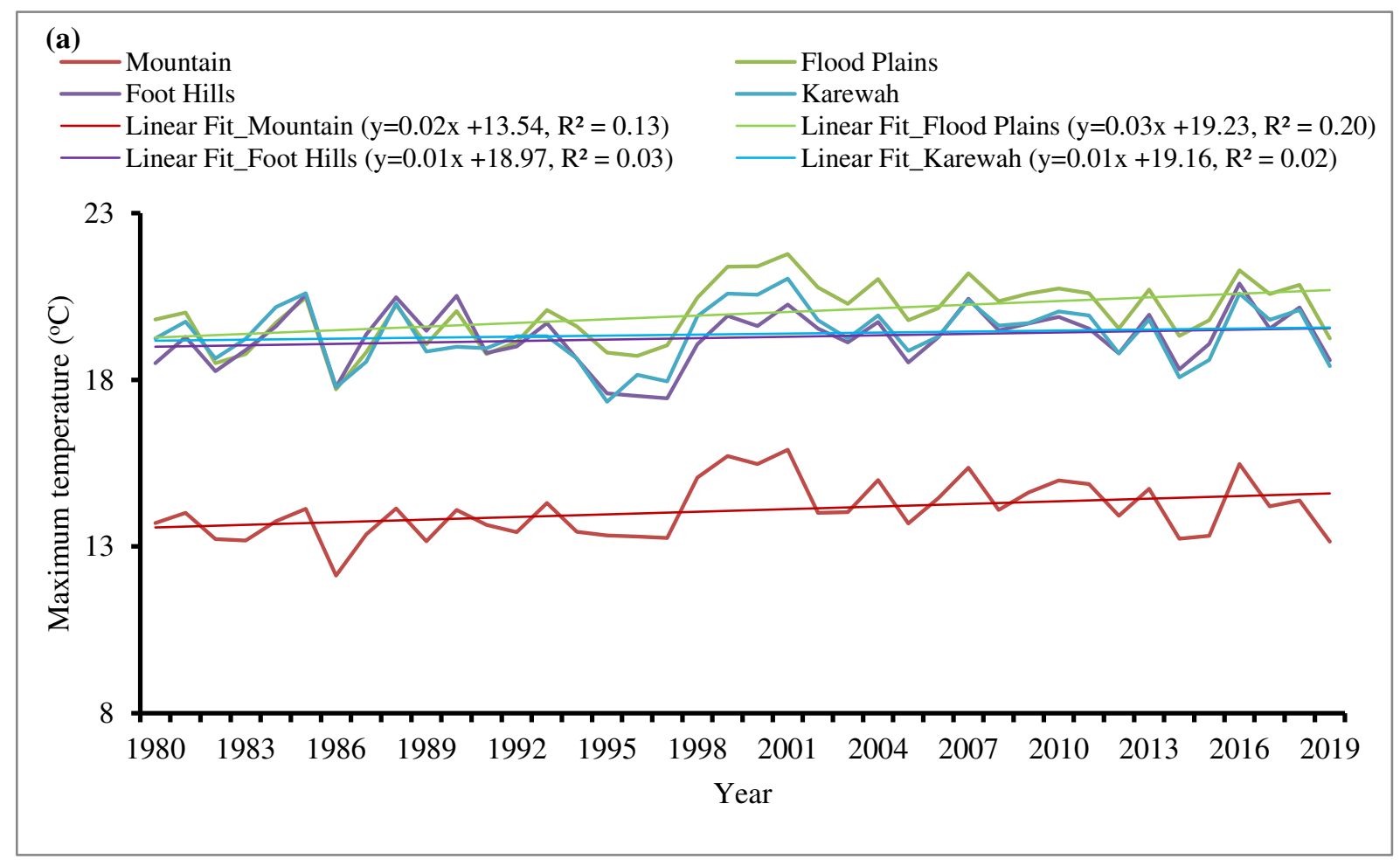



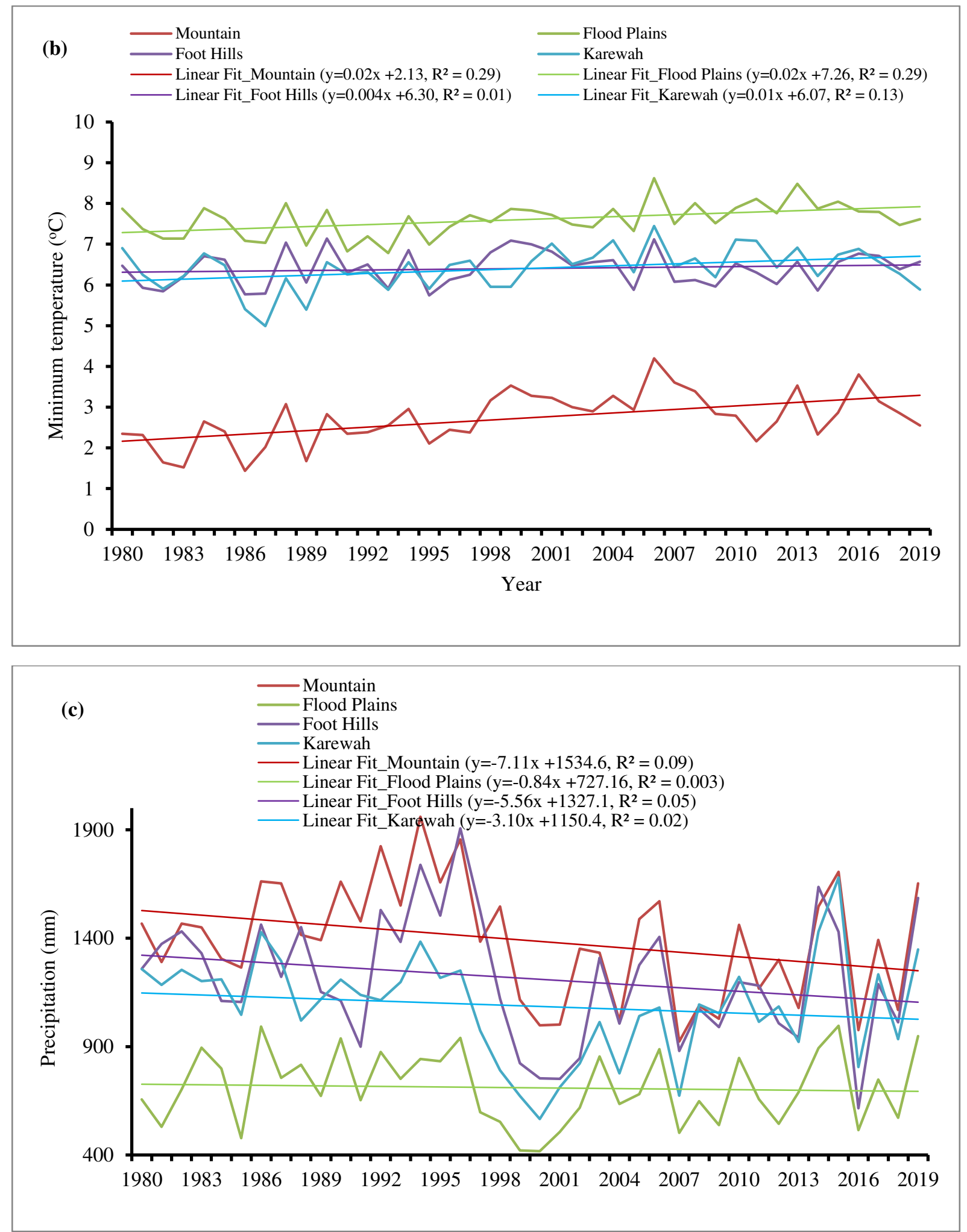

Fig. 5 Trends in mean (a) maximum temperature, (b) minimum temperature in degree Celsius and (c) precipitation $(\mathrm{mm})$ at different topographic zones of Kashmir Valley of UT-Jammu and Kashmir, India 


\subsection{Monthly, annual and seasonal analysis of precipitation}

The distribution of monthly precipitation exhibits more variation as compared to mean maximum and minimum temperatures at different regions of Kashmir (Fig 2c). Large variation in precipitation is observed during winter (January, February) and spring months (March, April). The perusal of data also revealed that Kashmir receives its maximum precipitation from January to April months under the influence of frequent western disturbances with winter precipitation forming major chunk of glaciers over high elevated mountainous region of the valley as main source of irrigation during the main Kharif (summer) season. From the data presented in Table $1 \mathrm{c}$, it is seen that large variation in $\mathrm{CV}$, skewness and kurtosis values have been observed for the month of September, October, November and December. Highest positive kurtosis (15.63) is observed for the month of September followed by October (7.02) and November (6.94), indicating outliers are present towards higher end. During the September 2014, Kashmir Valley experienced disastrous flood due to torrential rainfall of more than $300 \mathrm{~mm}$ within a week which is also evident from range of the data. Although maximum precipitation of more than $300 \mathrm{~mm}$ has also been recorded during February month but frequency of occurrences was more compared to September month hence CV values observed were less in comparison to September month. During the December month, the values of skewness and kurtosis were observed high indicating heavy tailed distribution with tendency of rainfall to remain above average.

Considering the correlation of precipitation with time indicates that precipitation is non-significantly $(p<0.05)$ decreasing at all stations except at station Gulmarg where, decreasing rate of precipitation was observed to be significant (Figure 3 a-f).

With regard to results of annual precipitation, the data showed a consistent decrease in the annual precipitation at the rate of $-5.01 \mathrm{~mm} /$ year. The sudden change was found in 1996 with no significant trend (Figure $4 c)$. The precipitation data, when analysed, seasonally shows decreasing rates of $-0.30,-4.95$, and -0.06 and -0.28 $\mathrm{mm} /$ year for the winter, spring, summer and autumn seasons, respectively (Table 2). The drop in spring precipitation was considered to be statistically important $(p=0.02)$. There have been major shifts in precipitation in the various topographical zones over the last decades (Fig. 5c). Although the mountainous area of the valley has seen a substantial drop in precipitation $(-7.11 \mathrm{~mm} /$ year) followed by foothills at $-5.56 \mathrm{~mm} /$ year. However, the Karewa and flood plains reported a modest to lower precipitation decline at -3.10 and $-0.84 \mathrm{~mm} /$ year, respectively (Fig. 5c). These results are consistent with the observations of Shafiq et al. (2019). In addition, the precipitation of the mountainous and foothill areas of the Kashmir Valley showed a declining pattern after 1997 with no major patterns in the Karewah and flood plain areas.

\subsection{Farmers perception of climate change}

In the present research, we have integrated the experience of progressive farmers from various topographical locations into the pattern analysis, the findings of which represent an important insight into the essence of the meteorological processes that could not have been feasible by the analysis of recorded data alone and the understanding of local processes perception offers clearer perspectives and knowledge related to a strategy that helps to overcome the complexities of sustainable agricultural production in the face of variable and unpredictable Kashmir environments. Based on the response of farmers, about $63 \%$ of the respondents from all surveyed locations had perceived that temperature trends have been increasing as compared with the situation just 40 years back and the $76 \%$ of the farmers believed that amount of rainfall and snowfall has been decreasing (Fig. 6). In the mountainous regions represented by Gulmarg and Pahalgam, about $80 \%$ of the farmers responded that 
precipitation has been decreasing for last three to four decades. Whereas, higher percentage of respondent (77.33\%) from flood plain region represented by Srinagar had perceived that temperature regimes have changed with the substantial increase over last four decades (Fig. 6). Beside the survey results, experience sharing of the farmers based upon three different locations of Kashmir has been mentioned under case study no. 1, 2 and 3) and from the discussion and experience as shared by the farmers, we concluded Kashmir region is witnessing a clear change in climate. It is therefore necessary to adjust the agricultural activity to the uncertainty situation and to improve expected climate change adaptation strategies in order to enhance the adaptive potential and resilience of farmers in these regions.

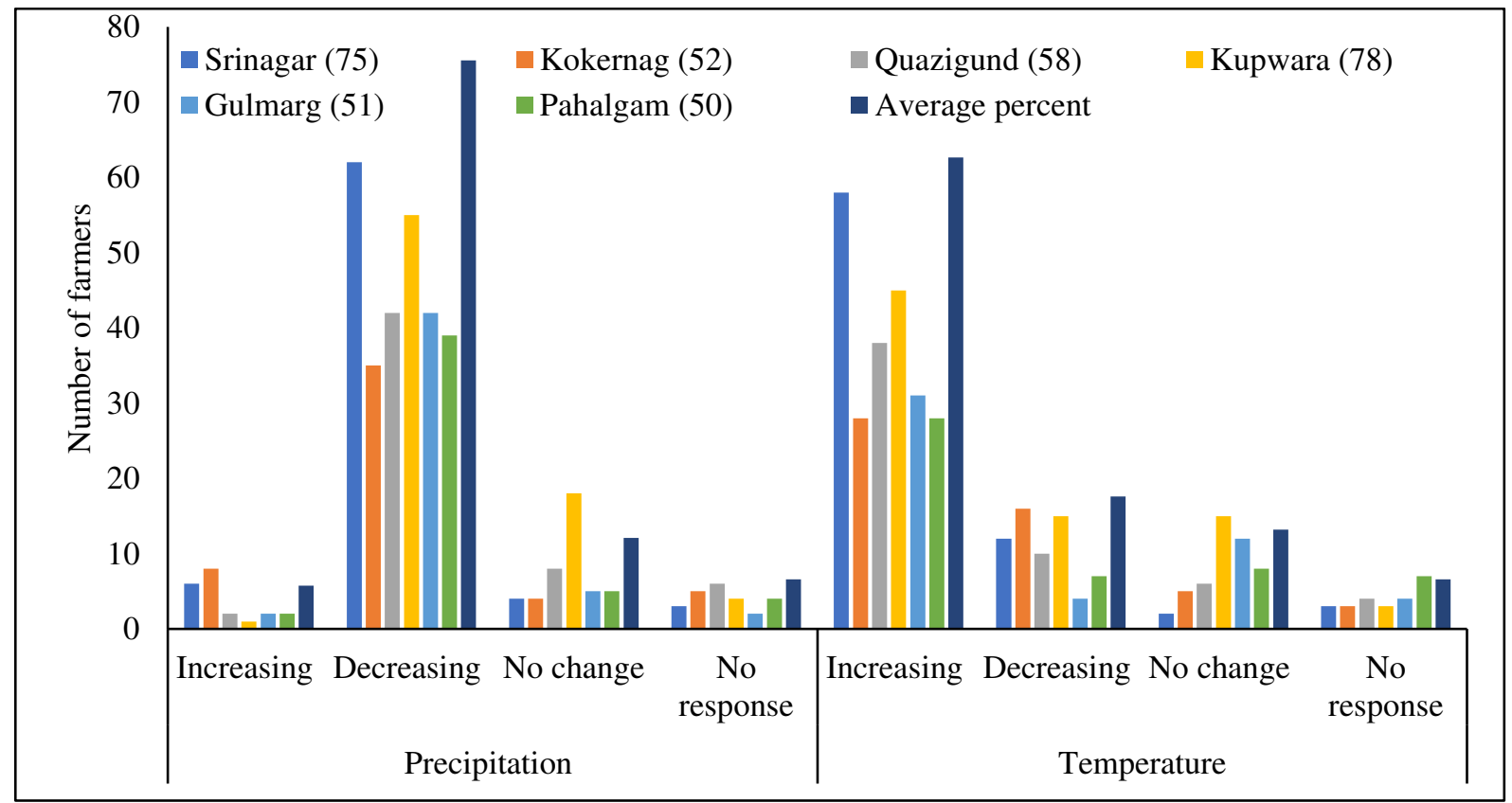

Figure 6. Response of farmers from different topographic zones of Kashmir Valley of UT-Jammu \& Kashmir on the trend of precipitation and temperature for the last 40 years. (Values in parenthesis indicate number of farmers interviewed at each site). Source: Own survey (2018-19)

\section{Case No. 1 Farming under uncertainty}

A progressive farmer (58 years old) from Batpora, Ganderbal, (flood plain region) namely Ab. Rasheed Kumar has shared his experience regarding the variability and erratic nature of precipitation as follows:

I've been living in this place since I was a kid and I've seen a lot of changes in weather parameters over time. Early before 1980s, we had experienced good precipitation in the form of snow and rainfall particular during the winter period (December to February) forming a major source of irrigation (in the form of glaciers) for our agricultural Kharif (Summer) season crops like rice as main crop and vegetables and pulses. Our forefathers and me could notice snow fall of 7-8 feet during those days. But in recent decades, we are experiencing drastic shortfall in rain and snow fall has to know few feet to inches. This has resulted the scarcity of our irrigation resources and has affected our agricultural crops. I can remember very recently in year 2018, prolonged drought conditions persisted in the whole Kashmir Valley and amid scant snowfall and rainfall during the winter, then the state Government, Jammu \& Kashmir advised farmers not to grow paddy this year and switch to other crops like maize and pulses. But at the same time, we cannot grow any other crop as rice has been our main crop and form the major source of our daily food. Things are now getting less stable and unable to foresee what will 
happen next; extended dry days lasting even two to four weeks during the main rainy season, and such changes in weather parameters have increased the occurrence of crop pests and diseases. In short, we are farming in the face of such uncertainties.

This testimony is in line with long-term meteorological variables, statistical performance, where annual precipitation has shown a substantial decreasing trend $(p=0.05)$ at the rate of $-6.63 \mathrm{~mm} /$ year under plain and mountain regions of Kashmir Valley.

\section{Case No. 2 Declining water resources and early flowering in crops}

A farmer namely Ab. Rashid Kumar (51 years old) from village: Chandilura, Tangmarg, Bramulla (hill region) has shared his experience as under:

The farmers of this region have been witnessing changes in temperature and rainfall particularly for last two decades. Temperatures are rising particularly winter temperatures. We can see early flowering in our apple orchids due to which yields per unit area are decreasing. Winter chill temperature are gone now and irrigation resources are declining with time. Many rivers and wetlands in the Kashmir regions are at risk of losing their seasonal existence, thereby impacting long-term water supply. To this end, we have also converted our paddy fields into horticulture apple orchid owing to scarcity of water/canal irrigation. Besides apple crop, farmers are now witnessing early flowering in oil seed and wheat crop which is resulting lower yields of these crops. In addition, the less precipitation and high temperature records from last many years has also damaged the high value crops like apple, saffron and walnut. Due to low rainfall the growth and colour remain dull as in apple and saffron which results in the low price and also reduces its taste. This perception of farmers pertaining to weather changes corroborates with our results, where an increase in temperatures have been observed in all seasons.

\section{Case No. 3 Lack of sufficient chilling hours}

A farmer namely Gh. Ahmad Mir (62 years old) from Kalaroos Kupwara (Karewah region) has shared his experience like:

Winter chill or temperature of $7^{\circ} \mathrm{C}$ or below are required in fulfilling the chilling treatments of various temperate fruits including apple, saffron, walnut and other winter cereals. At present, required number of chilling hours for winter crops is becoming difficult. What I am observing is that, there has been now less snow and rainfall during winter month especially in hilly areas of Kashmir. The necessity of cold treatments for temperate fruits for bud formation is very important. In summer, trees grow their vegetative and fruiting buds, and these buds will remain dormant before adequate chilling conditions have been accumulated. However, our fruit crops failed to obtain adequate cooling requirements due to the continuing weather warming, leading to several symptoms such as delayed leaf development, decreased fruit set and decreased fruit quality. The saffron production of the last several years has also been affected by the less snowfall and precipitation and the saffron production was recorded below average in 2015.

\section{Conclusion}

Our trend investigation revealed dynamic temperature and precipitation trends with increasing and decreasing pattern in Kashmir Valley. In general, despite differing patterns in mean maximum and minimum 
temperatures of various topographic locations, substantial rises in temperatures during the spring and winter seasons have been reported, which in turn would impact the winter crops of Kashmir Valley. Decrease in precipitation pattern is more evident and higher during spring season. Furthermore, we observed substantial decreasing rate of precipitation over mountain and foot hill regions of the valley, which will reduce the glacier mass, leading to reduced water flow, which in turn may hamper the perennial nature of Chenab, Jhelum and Indus rivers. The empirical results of this study were found in agreement with the perception and views of farmers which is in conformity with an increasing and decreasing trends of temperature and precipitation respectively over time. Therefore, in order to improve the adaptive capability and resilience of the marginal and smallholder farmers of the Kashmir Valley, it is necessary to adapt the farming operation to the situation of variability and design climate change adaptation strategies.

Conflict of Interest: Authors of the paper declare that they have no conflict of interest.

Funding statement: The work in this paper is a part of Indian Council of Agricultural Research, National Innovations on Climate Resilient Agriculture (ICAR-NICRA) funding project.

Authors contribution

\begin{tabular}{|l|l|l|}
\hline S. No & Name of the author & Role / Contribution \\
\hline 1 & Dr. S. Sheraz Mahdi (PI) & Conceptualization of project idea \\
\hline 2 & Bhagyashree S. Dhekale (Co-PI) & Statistical analysis of data \\
\hline 3 & Ashaq Hussain (Co-PI) & Assisted in conducting of farmers survey and data compilation \\
\hline 4 & Intikhab Aalum Jehangir (Co-PI) & Assisted in conducting of farmers survey and data compilation \\
\hline 5 & Rukhsana Jan (SRF) & Working as Senior Research Fellow in the project \\
\hline 6 & M. Anwar Bhat (Co-PI) & Assisted in conducting of farmers survey and data compilation \\
\hline 7 & Najeebul Rehman Sofi (Co-PI) & Organizing survey program /data compilation \\
\hline 8 & Latief Ahmed (Co-PI) & Assisted in meteorological data analysis \\
\hline 9 & Asif M. Iqbal Qureshi (Co-PI) & Data base management of weather files /analysis \\
\hline 10 & Aziz Mujtaba Aezum (Co-PI) & Assisted in Manuscript writing \\
\hline 11 & Shabir A. Bangroo, (Co-PI) & Assisted in weather data base management \\
\hline 12 & Owais Ali Wani (PhD student) & Map creation and designing using QGIS \\
\hline 13 & F.A. Bahar (Co-PI) & Assisted in Manuscript writing \\
\hline
\end{tabular}

Availability of data and material: Data and materials are available with the Division of Agronomy, Faculty of Agriculture, Sher-e-Kashmir University of Agricultural Sciences \& Technology of Kashmir (SKUAST-K) and will be made available to any user upon formal request to corresponding author.

Code Availability: NA

Ethics approval: The work in this paper is original piece of work that has been carried out under the ICARNICRA sponsored project. The paper or its part has not been submitted to any other journal for its publication. The results of the paper have been presented clearly and without any manipulation. No data, text of any other have been used.

Consent for publication: I, the corresponding author has taken consent from all authors and provide consent for the publication of this paper in the prestigious journal of "Theoretical and Applied Climatology".

Consent for participation: The corresponding author declares that all authors of this paper have participated in the research work and has contributed as mentioned above. 


\section{Acknowledgement}

The authors express their gratitude to ICAR-CRIDA, NICRA, Hyderabad for funding the project and acknowledges the Indian Meteorological Department (IMD), Pune, Maharashtra and Rambagh, Srinagar for providing the necessary weather data. Authors are also grateful to farmers of different surveyed locations of Kashmir valley for sharing the information regarding weather/climate changes of their area.

\section{References}

Belay S, Zaitchik BF, Foltz J D (2014) Agroecosystem specific climate vulnerability analysis: application of the livelihood vulnerability index to a tropical highland region. Mitig. Adapt. Strategies Glob. Change 27. https://doi.org/10.1007/s11027-014-9568-1.

Bhutiyani MR, Kale VS, Pawar NJ (2007) Long-term trends in maximum, minimum and mean annual air temperatures across the north western Himalaya during the 20th century. Clim Chang 85:159-177

Bhutiyani MR, Kale VS, Pawar NJ (2010) Climate change and the precipitation variations in the north-western Himalaya: 1866-2006. Int J Climatol 30:535-548

Brohan P, Kennedy JJ, Harris I, Tett SFB, Jones PD (2006) Uncertainty estimates in regional and global observed temperature changes: anew data set from 1850. J Geophys Res 111(D12): D12106. https://doi.org/10.1029/2005JD006548

Dash SK, Jenamani RK, Kalsi SR, Panda SK (2007) Some evidence of climate change in twentiethcentury India. Climate Change 85(3-4): 299-321. https://doi.org/10.1007/s10584-007-9305-9.

Dimri AP and Dash SK (2012) Wintertime climatic trends in the western Himalayas. Clim Chang 111(34):775-800. https://doi.org/10. 1007/s10584-011-0201-y

DST (2018) Report on climate vulnerability assessment for the Indian Himalayan region using a common framework. Publisher, Department of Science \& Technology, Govt of India, New Delhi, pp. 60.

Gilbert RO (1987) Statistical methods for environmental pollution monitoring. Van Nostrand Reinhold, New York.

Helsel, D R and Hirsch R M (1992) Statistical methods in water resources. Elsevier, Amsterdam, 522 pp.

Hirsch RM, Alexander RB, Smith RA (1991) Selection of methods for the detection and estimation of trends in water quality. Water Resour. Res. 27, 803-814.

Huth R, (1999) Testing for trends in data unevenly distributed in time. Theor. Appl. Climatol. 64, 151-162

Immerzeel W, Van Beek L P H and Bier kens M F P (2010) Climate change will affect the Asian water towers, Science, $328,1382-1385$

IPCC (2013) Climate change: the physical science basis. In: Stocker TF, Qin D, Plattner G-K, Tignor M, Allen SK, Boschung J, Nauels A, Xia Y, Bex V, Midgley PM (eds) Contribution of Working Group I to the Fifth Assessment Report of the Intergovernmental Panel on Climate Change. Cambridge University Press, Cambridge, 1535 pp. https://doi.org/10.1017/CB09781107415324

IPCC (2007) Climate Change: Impacts, Adaptation and Vulnerability. Cambridge University Press, Cambridge, United Kingdom and New York, USA. 
IPCC, 2018: Summary for Policymakers. In: Global warming of $1.5^{\circ} \mathrm{C}$. An IPCC Special Report on the impacts of global warming of $1.5^{\circ} \mathrm{C}$ above pre-industrial levels and related global greenhouse gas emission pathways, in the context of strengthening the global response to the threat of climate change, sustainable development, and efforts to eradicate poverty [V. Masson-Delmotte, P. Zhai, H. O. Pörtner, D. Roberts, J. Skea, P. R. Shukla, A. Pirani, W. Moufouma-Okia, C. Pean, R. Pidcock, S. Connors, J. B. R. Matthews, Y. Chen, X. Zhou, M. I. Gomis, E. Lonnoy, T. Maycock, M. Tignor, T. Waterfield (eds.)]. World Meteorological Organization, Geneva, Switzerland, 32 pp.

Jaagus J (2006) Climatic changes in Estonia during the second half of the 20th century in relationship with changes in large-scale atmospheric circulation. Theor. Appl. Climatol. 83, 77-88.

Johnson M (2003) Lose something? ways to find your missing data, Houston Center for Quality of Care and Utilization, Studies Professional Development Series: 17-09.

Kendall MG (1975) Rank Correlation Methods, second ed. (New York: Hafner).

Mann HB (1945) Nonparametric tests against trend. Econometrica 13, 245-259.

Mosmann V, Castro A, Fraile R, Dessens J, Sanchez JL (2004) Detection of statistically significant trends in the summer precipitation of mainland Spain. Atmos. Res. 70, 43-53.

NOAA (2020), National Centers for Environmental Information, State of the Climate: Global Annual Climate Report published online January 2020, retrieved on March 27, 2020. https://www.ncdc.noaa.gov/sotc/global/201913.

Nengroo ZA, Bhat MS, Kuchay NA (2017) Measuring urban sprawl of Srinagar city, Jammu and Kashmir, India. Journal of Urban Management, 6(2): 45-55. https://doi.org/10.1016/j.jum.2017.08.001

Pawe et al. (2019) The Heat is on in the Himalayas: Assessing Srinagar's Urban Heat Island Effect (A book chapter in Environmental Change in the Himalayan Region, pp 157-171.Online: https://link.springer.com/chapter/10.1007/978-3-030-03362-08

Pepin N, Bradley R, Diaz H. et al (2015) Elevation-dependent warming in mountain regions of the world. Nature Clim. Change 5, 424-430 https://doi.org/10.1038/nclimate2563

Pielke RA Sr, Stohlgren T, Parton W, Doesken N, Money J, Schell L 2000 Spatial representativeness of temperature measurements from a single site. Bull Am Meteorol Soc 81:826-830.

Romshoo S A, Altaf S, Rashid I, Dar RA (2017) Climatic, geomorphic and anthropogenic drivers of the 2014 extreme flooding in the Jhelum basin of Kashmir, India, Geomatics, Natural Hazards and Risk, 9, 224248.

Romshoo SA, Dar RA, Rashid I, Marazi A, Ali N, Zaz SN (2015) Implications of Shrinking Cryosphere under Changing Climate on the Stream flows of the Upper Indus Basin, Arct. Antarct. Alp. Res., 47, 627-644.

Rosenberg NJ, Brownb RA, Izaurralde RC, Thomsona, AM (2003) Integrated assessment of Hadley Centre (HadCM2) climate change projections on agricultural productivity and irrigation water supply in the conterminous United States I. Climate change scenarios and impacts on irrigation water supply simulated with the HUMUS model. Agric. For. Meteorol. 117, 73-96

Rosenberg NJ, Brownb RA, Izaurralde RC, Thomsona AM (2003) Integrated assessment of Hadley Centre (HadCM2) climate change projections on agricultural productivity and irrigation water supply in the conterminous United States I. Climate change scenarios and impacts on irrigation water supply simulated with the HUMUS model. Agric. For. Meteorol. 117, 73-96 
Sen PK (1968) Estimates of the regression coefficient based on Kendall's tau. J. Am. Stat. Assoc. 63, 1379-1389.

Shafiq MU, Rasool R, Ahmed P, Dimri AP (2018) Temperature and Precipitation trends in Kashmir valley, North Western Himalayas, Theoretical and Applied Climatology, 1-12, doi.org/10.1007/s00704-018-2377-9

Shafiq MU, Bhat MS, Rasool R, Ahmed P, Singh H, Hassan H (2016) Variability of precipitation regime in Ladakh region of India from 1901-2000. J Climatol Weather Forecast 4(2):165. https://doi.org/ $10.4172 / 2332-2594.1000165$

Shafiq MU, Islam ZU and Ahmed AP (2019) Recent trends in precipitation regimes in Kashmir Valley. Disaster Advances 12(4):1-11.

Sharma KP, Moore B, Vorosmarty CJ III (2000) Anthropogenic, climatic and hydrologic trends in the Kosi Basin, Himalaya. Clim Chang 47: 141-165

Shekhar M S, Chand H, Kumar S, Srinivasan K, Ganju A. (2010). Climate-change studies in the western Himalaya. Annals of Glaciology 51(54): 105-112.

Solomon S, Qin D, Manning M, Chen Z, Marquis M, Averyt KB, Tignor M, Miller HL (Eds.) (2007) Climate change (2007): the physical science basis, Contribution of Working Group I to the Fourth Assessment Report of the Intergovernmental Panel on Climate Change Cambridge University Press, Cambridge, United Kingdom and New York, NY, USA, pp. 996

Tabari H, Marofi S, Ahmadi M, (2011) Long-term variations of water quality parameters in the Maroon River. Iran. Environ. Monit. Assess. 177, 273-287

Wang JS, Chen FH, Zhang GQ (2008) Temperature variations in arid and semi-arid areas in middle part of Asia during the last 100 years. Plateau Meteorol 27:1035-1045.

Yao J and Chen Y (2015) Trend analysis of temperature and precipitation in the Syr Darya Basin in Central Asia, Theor Appl Climatol 120: 521-531DOI https://doi.org/10.1007/s00704-014-1187-y, 3-4, 531

Zhang Q, Xu CY, Zhang Z, Chen YD (2008) Changes of temperature extremes for 1960-2004 in Far-West China. Stoch. Environ. Res. Risk Assess. doi:10.1007/ s00477-008-0252-4. 


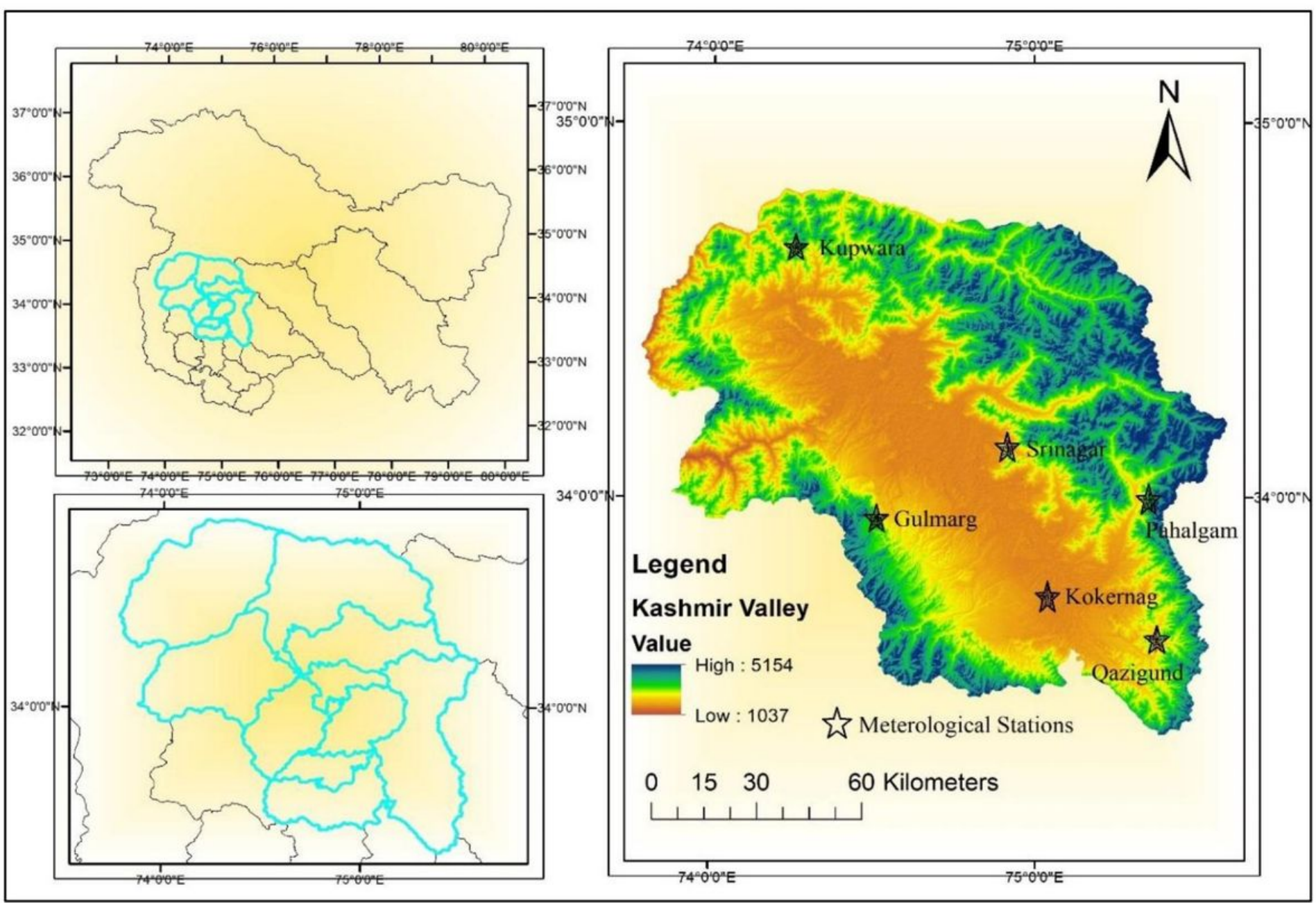

Figure 1

Map showing the locations and elevation $(\mathrm{m})$ of six meteorological stations used in the study viz., Srinagar (flood plain, located on plane surface), Quazigund (foot hills, located on plane surface), Gulmarg and Pahalgham (Mountainous, located on mountain top), Kupwara (Karewa's, located on plane surface bounded on three sides by mountains) and Kokernag (Karewa's, located on plane surface) of UT-Jammu \& Kashmir. Data period used: (1980-2019) Note: The designations employed and the presentation of the material on this map do not imply the expression of any opinion whatsoever on the part of Research Square concerning the legal status of any country, territory, city or area or of its authorities, or concerning the delimitation of its frontiers or boundaries. This map has been provided by the authors. 

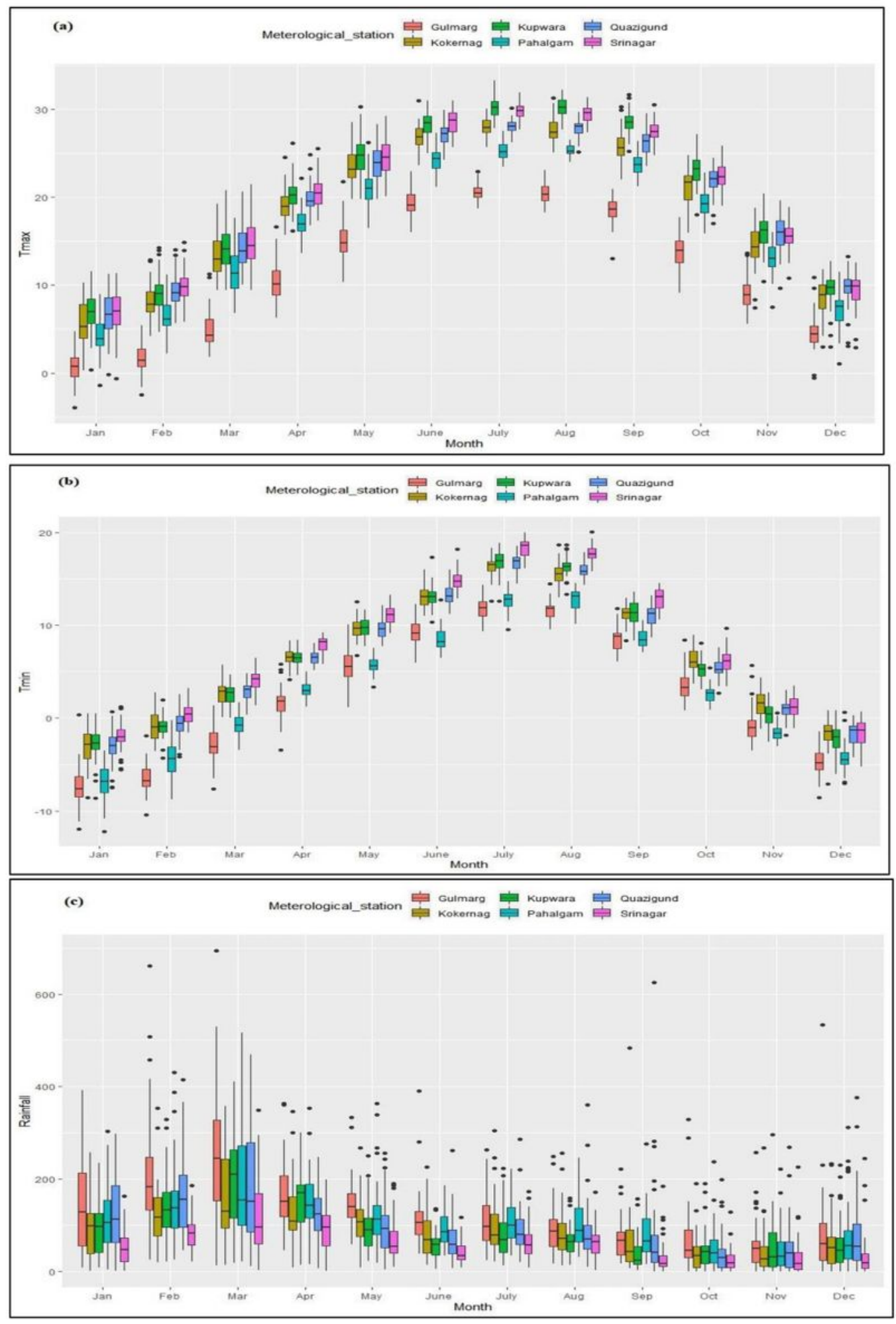

Figure 2

Mean monthly (a) maximum, (b)minimum and (c) rainfall of six meteorological stations from 1980-2019 representing Kashmir Valley of UT-Jammu \& Kashmir, India 

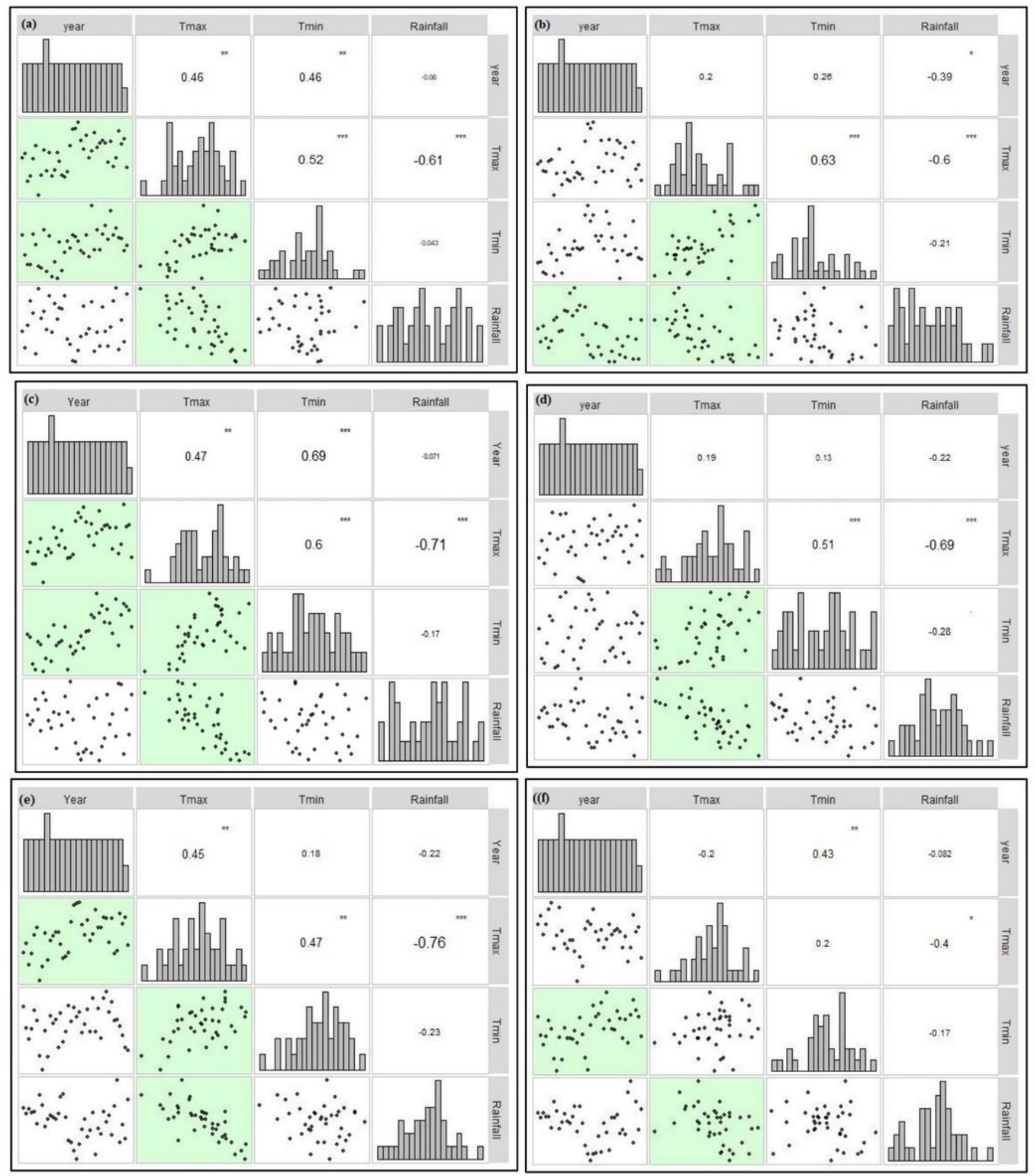

\section{Figure 3}

(a-f) Pair plot of correlation matrix among different weather variables across six meteorological stations viz. (a) Srinagar, (b) Gulmarg, (c) Pahalgham, (d) Quazigund, (e) Kupwara and (f) Kokernag of Kashmir valley of UT-Jammu and Kashmir, India. Data period used: (1980-2019) 

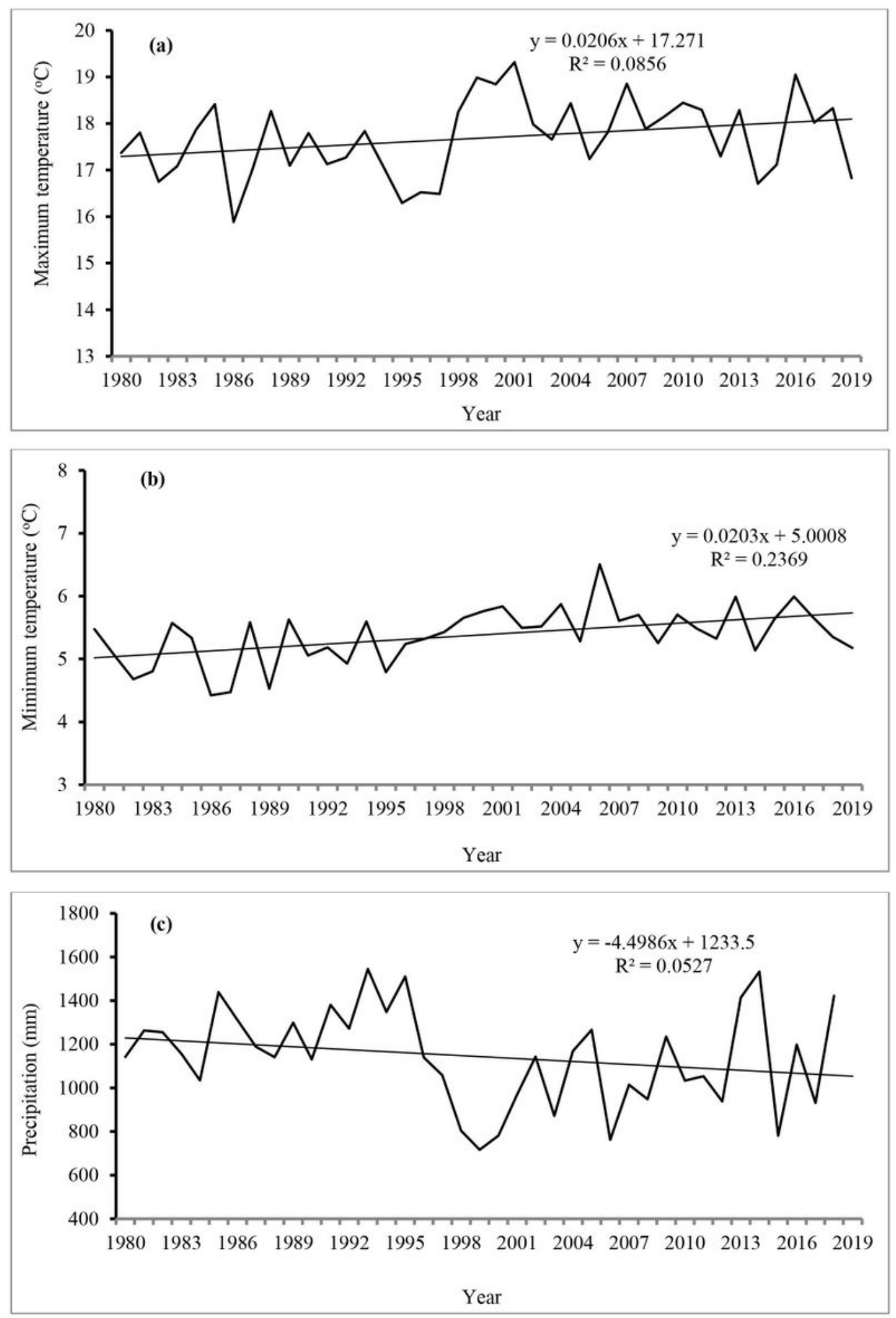

\section{Figure 4}

Trends of mean annual (a) maximum (b) minimum temperature and (c) rainfall of Kashmir Valley of UTJammu \& Kashmir, India 

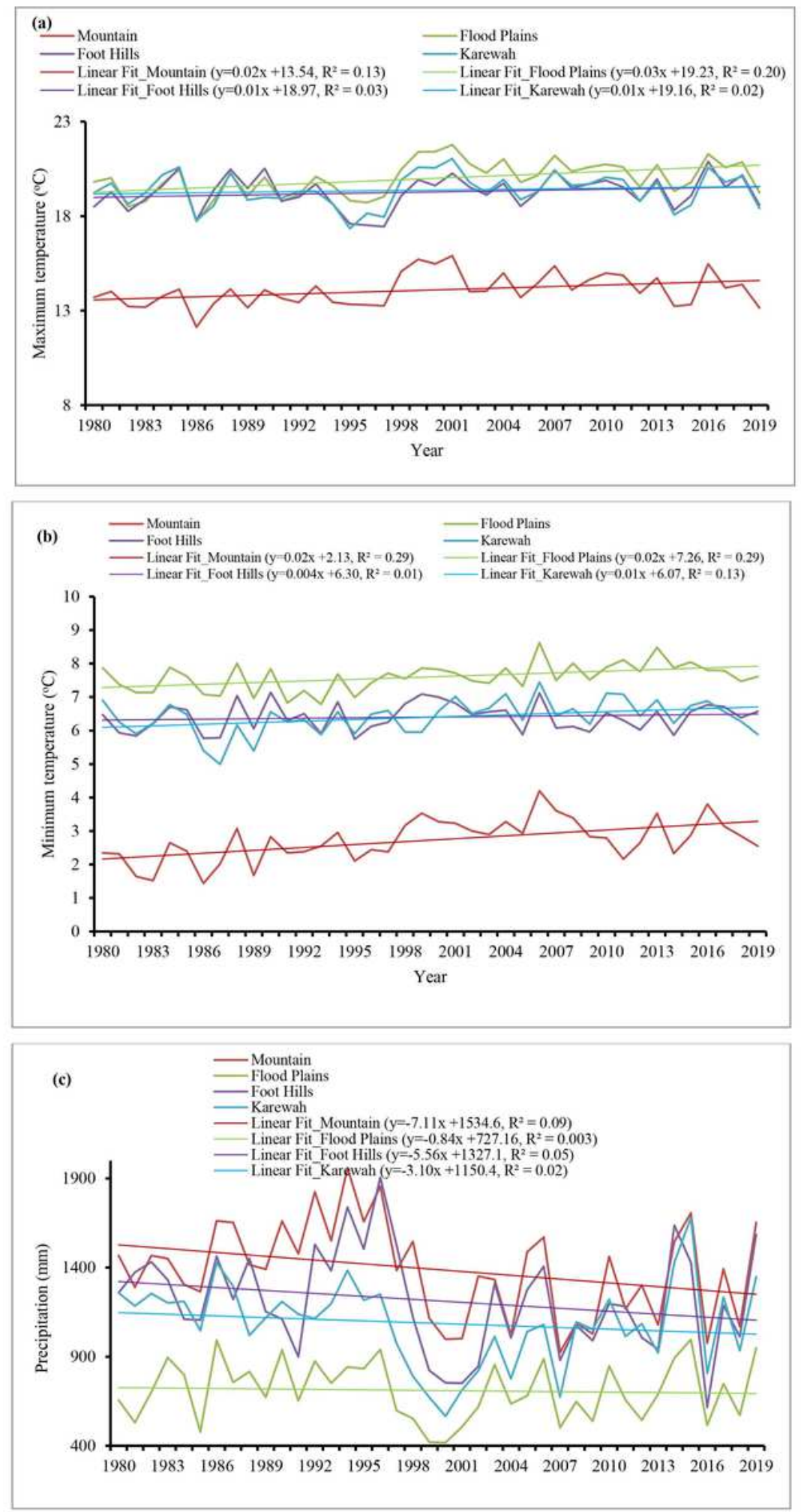

\section{Figure 5}

Trends in mean (a) maximum temperature, (b) minimum temperature in degree Celsius and (c) precipitation $(\mathrm{mm})$ at different topographic zones of Kashmir Valley of UT-Jammu and Kashmir, India 


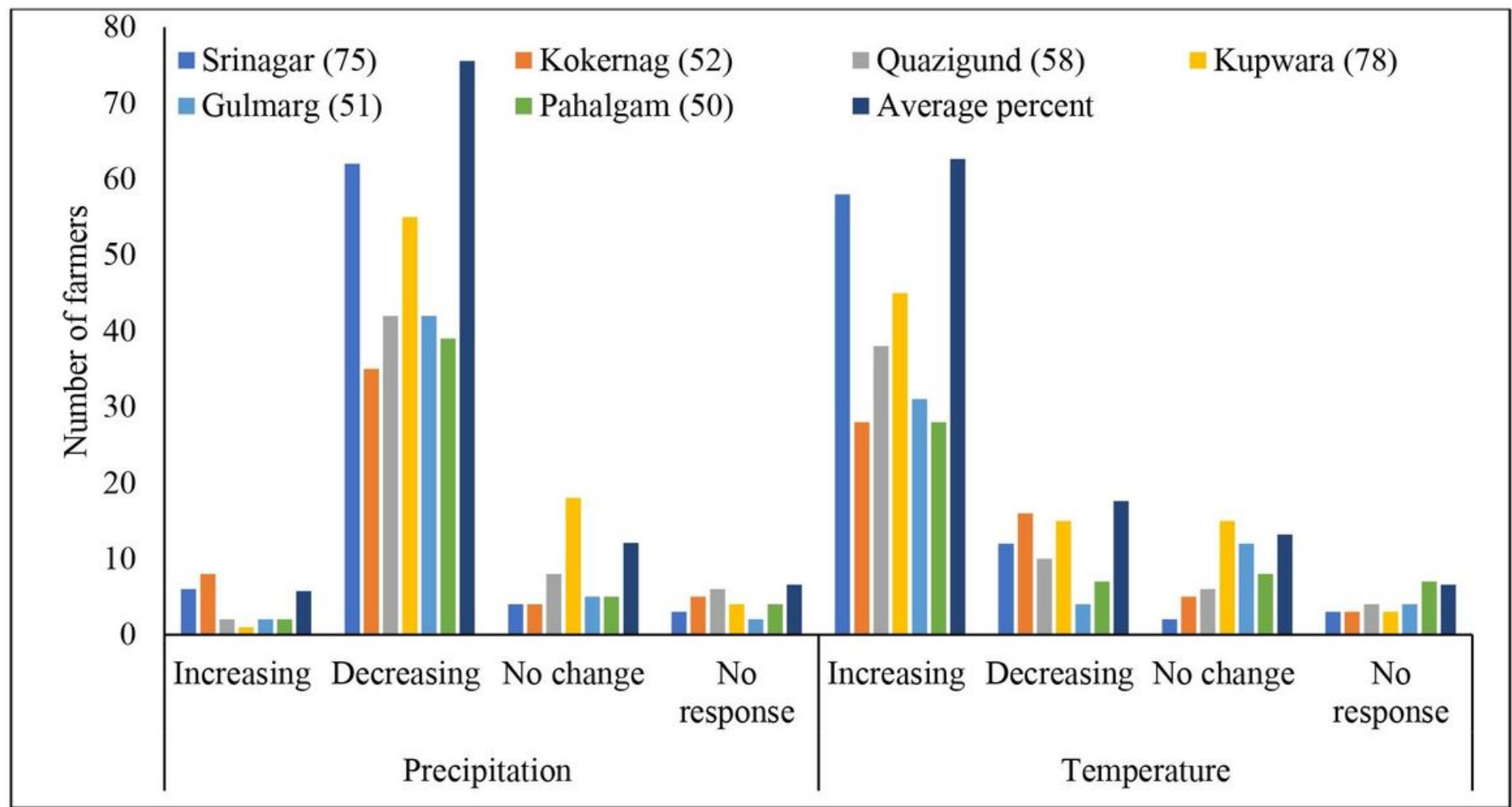

Figure 6

Response of farmers from different topographic zones of Kashmir Valley of UT-Jammu \& Kashmir on the trend of precipitation and temperature for the last 40 years. (Values in parenthesis indicate number of farmers interviewed at each site). Source: Own survey (2018-19) 